\title{
Fieldwork@40: Fieldwork in Geography Higher Education
}

Derek France ${ }^{a}$ and Martini Haigh ${ }^{b}$

aDepartment of Geography and International Development, University of Chester, Chester, UK

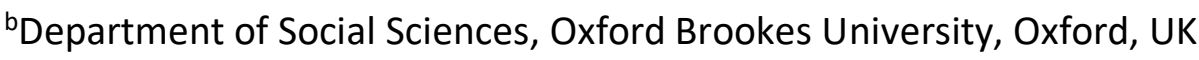

\section{Abstract}

Fieldwork is the most powerful learning invitation in the toolkit of Geographical Education. This review of papers in The Journal of Geography in Higher Education (JGHE) suggests seven modes in the development of fieldwork. These are arrayed as a kind of historical, perhaps evolutionary, sequence but most remain current in Geography fieldwork practice. At the far end (1960's) of the sequence are didactic modes that are teacher centred and use the field as an adjunct to the classroom, in the middle (1990's) are modes that involve active learning and focus on the development of students as investigators, and at the near end (2010's) are those that centred on the field study area and its qualities, that involve concern about the ethics of student engagement and that employ blended learning technologies. The review charts the JGHE's gradual shift away from its original, almost exclusively, UK-focus toward something rather more international and inclusive. Fieldwork is where Geographers learn 'from doing' Geography to 'do' Geography. Its special attributes include providing experiential, sometimes transformative, learning through the immersion of the learner in the field experience. In 40 years, JGHE has helped Geography Fieldwork move from the margins of the curriculum to its current place at its core. 


\section{Introduction.}

Fieldwork is one of the most powerful learning invitations in the toolkit of Geographical Education. It is a signature pedagogy of Geography and a near-unique selling point (SpronkenSmith, 2013; Hovorka \& Wolf, 2009). Fieldwork learning develops a significant part of the key skill set of the Geography graduate (Gold et al, 1991). Field courses help learners integrate theoretical and practical concepts, forming an experiential bridge between classroom learning and the real-world (Hovorka \& Wolf, 2009; Fuller et al., 2006). They build skills in field observation and comprehension that build problem solving capabilities (Maskall \& Stokes, 2008). They also demonstrate the limitations and inadequacies of textbook and classroom learning, so fostering critical self-awareness, while providing a useful mode of selfdevelopment through close encounters with the 'Other' (Monk, 2000), both environmental and human (Hovorka \& Wolf, 2009; Pawson \& Teather, 2002). The consequence is that faced with a field situation to interpret or a problem to solve, a good Geography graduate knows what to do to find an explanation or a solution. Geographers have the skills needed to become the "world-makers" ("visvakarma"-s), envisaged by Rabindranath Tagore, able to demonstrate the "union of education and life" and act for the welfare of all (Tagore, 1930, p 42-43). Graduates from other disciplines or, indeed geography programmes (Mullens, Bristow, \& Cuper, 2012), where the focus is upon written texts, laboratory work, and computer simulation, often lack such capabilities.

Fieldwork provides the qualities of a holistic education, which cannot be gained in the classroom or by other kinds of study (Gallego Nava, 2001). It provides the experiential benefits that emerge from total immersion of the learner in real world situations that contain influences and challenges that exceed their own imaginings or preconceptions and that have a direct, often emotional, impact (Kern \& Carpenter, 1984). Geographical fieldwork is a connective practice (Haigh, 2017), something that creates an empathic and emotional, sometimes conative, relationship between the learner and an 'Other' (Monk, 2000). 'Otherness', of course, is an attitude constructed by the mind of the observer; the 'Other' is something different to the familiar and everyday norm, a perceived 'them' that is different from 'us' (Staszak, 2009). It is the 'Otherness' of the field experience that helps surface the spectra that divide the familiar from the alien', the communal from the private, sacred from profane, the ordered from the chaotic, and which influence the degree to which different places have emotional or conative affect (cf. Ellis, 1993; Haigh, 2008, 2017). It is not for nothing that the Deep Ecology pedagogy of Arne Naess emphasised his own wilderness epiphany at Tvergastein, Norway, a deep 
experience of one-ness within Nature that still provides a foundation stone for this major species of environmentalism (Drengson \& Inoue, 1995). However, the experience of fieldwork can be equally, often more, traumatic and transformational when it tackles human situations, often producing intense experiences not unlike the transformational acculturation process that affect those who immerse themselves in another culture for the purposes of higher education (cf. Trahar, 2011; Haigh, 2013). The affective power of immersion in a field situation is usually powerful. There remains truth in the anthropologist's adage: "You don't do fieldwork, fieldwork does you" (Simpson, 2006, p.129). Field trips change attitudes as much as they foster learning (Kern \& Carpenter, 1986). This is why fieldwork is sometimes seen as 'an initiation rite' (Rose, 1993, p.69) that creates the Geographer's 'locus of becoming' (Powell, 2002, p 267)

Fieldwork is also something that is perpetually under threat by the cost-savers of Higher Education management. It is expensive, demanding of staff time and can create major challenges because of the complexities of dealing effectively with Health and Safety and inclusivity issues (Jenkins, A., 1994; Hall et al., 2002). Maskall and Stokes (2008) detail the many design, logistic, legal and other practical issues associated with organising fieldwork experiences. Of course, the effectiveness of fieldwork depends upon how it is done and, equally, how well it supports and is integrated into the larger curriculum (McEwen, 1996; Haigh \& Gold, 1993; Glass, 2015a).

What is certain, however, is that Geography courses seem impoverished when fieldwork is removed. Fuller, Gaskin \& Scott (2003) explored the impact of the removal of fieldwork from the curriculum, something caused by the restriction of access to rural areas caused by an outbreak of Foot and Mouth disease among farm livestock in the UK in 2001. This study of around 300 students at 5 UK Universities found that learners agreed that fieldwork was both a positive experience and made a course 'better'. Deprived of fieldwork, many felt that their learning was diminished and that they had missed out on a chance both to connect their learning with the real world and to build technical skills. Their teachers agreed that the loss of fieldwork in 2001 had removed key learning opportunities and reduced social bonding in the cohort (Scott, Fuller, \& Gaskin, 2006). These results are supported by those collected elsewhere (Dunphy \& Spellman, 2009). At the University of Toronto, Leydon \& Turner (2013) describe a post-field-course boost in engagement with Geography and a better community among learners and teachers, while Houser et al. (2011) report that fieldwork participants score 
significantly better grades than those who did not participate. When fieldwork's educational benefits are discussed; at the forefront is its ability to immerse learners in 'real-world' experiences that connect them, affectively, with the value of Geography as a discipline, with the needs of their fieldwork areas, and, if all goes well, with their personal citizenship responsibilities. Boyle et al. (2007) explored the affective domain of fieldwork and found that most participants agreed that the experience had greater academic value than library work in helping them develop problem-solving and employability-related skills and in deepening their understanding of Geography.

This brief overview reviews the changing nature and type of 'field-based' publications in the JGHE. It evaluates changes in the key concerns and emphasis in such papers over a forty-year period and it suggests some areas, for future research.

\section{Figure 1 about here}

\section{Quantifying change}

The potential change in field-based publications over the last forty years of the journal were reviewed through assessing the frequency of the term 'field' and allied words in article titles (see Figure 1). The number of publications recorded were normalised to the proportion of available articles within any given year, since the journal's frequency of publication increases over time. Key words were excluded from the analysis, since they do not span the full forty years of the journal and were only introduced in 1994. Figure 1 indicates 129 publications explicitly identifiable as field-based, showing their fluctuating frequency over forty years and an overall increasing trend. The annotated peaks in 1987, 1996 and 2015 reflect the willingness of practitioners to organise special collection of papers or emerging themes driven at times by external factors (e.g. transferable skills agenda in the mid 80's or the rise of Internationalisation in 2000). The next section suggests that, over time, there have been at least seven modes in the development of the fieldwork narrative.

\section{Seven Modes of Fieldwork}

Seven modes of fieldwork practice have been identified from the 129 fieldwork papers published by the JGHE. Each mode is characterised by a different form of student and staff engagement with fieldwork. Figure 2 illustrates an evolutionary sequence of change in 
fieldwork practice from didactic modes that are teacher centred and use the field as an adjunct to the classroom, through modes that involves active learning and focus on the development of students as investigators. More contemporary modes centre on the field study area and its qualities; they care about the ethics of student engagement with the study area and teaching is both blended with and enabled by information technologies. Our analysis is underpinned by a short discussion of the characteristics of each mode.

Figure 2 about here

\section{Mode 1: Teacher Centred ('look and get back in the bus').}

Traditional modes of Geography fieldwork, typical of the period from 1950 into the 1970s (Kent et al., 1997), often wasted its potential by reducing the experience to an extended classroom, its sights offered as illustrations of the teacher's mental textbook, displayed during occasional 'Cook's Tour' coach stops. Learning was passive, observational, superficial - a catalogue of sites and sights, perhaps to be regurgitated later as examples in essays or examination. In the worst cases, field courses were stand-alone excursions, remote from the main business of classroom instruction and ignored by assessment.

\section{Mode 2: The Field as Laboratory ('do and learn')}

This mode of Geography Fieldwork, current from the 1960s onwards, involves active learning. However, following Wooldridge and East (1951), it sees and employs the field as a kind of teaching laboratory for surveying, mapping, field-sketching (Board, 1965). The aim is to build specific skills, usually practical skills, and the character of the field site is entirely subordinate to this aim. Its priority is the technique while the landscape tends to be explored as a number of measurable parts rather than a functioning whole (Finlayson, 1981; Gray, 1981, Keene, 1982). Such field courses, still common, especially in scientific Physical Geography contexts, are created to teach learners how to use data collection instruments, record soil profiles, administer questionnaires, conduct interviews, measure river flows, and so on (Moles, 1977; Kasimov, Chalov \& Panin, 2013). The emphasis is upon using the technique, e.g. morphological mapping, correctly, to record plausible results in a field notebook and to interpret them correctly.

An important subtheme in this mode is the use of thematic trails, as promoted by Peter Keene (1989). Here, the approach remains teacher prescribed, the learner follows a pre-set trail through a landscape and responds to questions or information or collects data at specified 
locations in response to written prompts from the trail designer. The trail can be real-world or, more recently, virtual. In content, it can range from simply giving instruction to participants (after the fashion of a municipal city walk), it can involve them answering questions or solving puzzles after the fashion of many video games and it can involve them in using survey equipment perhaps collecting data towards some other goal (Clark, 1997). Although most trails are teacher constructed, sometimes their construction is done by learners as coursework (Higgitt, 1996a).

\section{Mode 3: Project-oriented ('Learning in Teams as preparation for the Real World')}

O'Riordan (1978, p.3) argued that an "educational exercise should always promote an understanding of how the world outside the classroom operates". He describes a year long, project-based field course tackling the problems of environmental degradation in the UK's Norfolk Broads. In 1981, Silk \& Bowlby contrasted the demands of project work with "those of organised fieldwork" and noted its contribution to it being seen as a "useful and relevant" discipline (Silk \& Bowlby, 1981, p.155-156).

A few years' later, project-oriented teamwork began to be seen as a key mode for fieldwork along with dealing with the problems of student team-working (Haigh \& Gold, 1993). However, despite its many problems, more learners often feel more confident about being able to engage in teamwork after undertaking fieldwork (Boyle et al., 2007). From the 1990s, teamworking and problem-based and inquiry-based approaches to field working became major fieldwork themes. These approaches helped connect learners, actively and directly, with issues

that faced their field areas, ideally helping them to connect theory and practice, and also helping forge deeper links between teaching and research (Pawson et al., 2006; Spronken-Smith et al., 2008). Increasingly, undergraduates are being enabled to 'do' fieldwork for themselves. Today's innovators experiment with fieldwork learners acting as fieldwork leaders for their peers (Marvell, et al., 2013).

\section{Mode 4: Curriculum Centred ('Look, learn, do, use and be assessed')}

During the 1990s, the UK's belated expansion (some say 'massification') of Higher Education ushered in a new era of accountability and cost cutting that forced the justification of fieldwork and challenged its conventional models (Higgitt, M., 1996; Jenkins, T., 1994; Kent et al., 1997). Previously, fieldwork was often undertaken as a stand-alone and largely self-contained activity; it was unassessed and, once done, largely ignored by further teaching. Now, fieldwork, 
branded as expensive, risky, suspiciously 'out-of-office' and, hence, generally unloved by University managers, had to be justified.

Graves (1978) ignores fieldwork entirely in his early JGHE essay on Geography curriculum design. However, subsequently, recognising that 'Geographers learn through the soles of their feet', fieldwork became stablished as the heartwood of the Geography curriculum (McEwen, 1996; Lloyd et al., 2015, Gold et al., 1991). Martin Higgitt (1996b) recognised four skill groups developed by Geography fieldwork: deeper intellectual understanding of Geography, personal and vocational skills, technical skills in research methods, and experience-related skills. Recently, such thinking has blossomed into writings that link fieldwork closely to the development of the general and discipline-specific 'graduate attributes' including emotional intelligence, critical thinking, problem solving and global citizenship (Couper \& Porter, 2016; France et al, 2016; Fuller \& France, 2016; Haigh, 2016; Hill \& Walkington, 2016; Hill, Walkington, \& France, 2016; Spronken-Smith et al, 2016).

\section{Mode 5: Technologically-enhanced (Map or video, then ground-truth')}

From early rumblings in the later 1980s, but especially since the mid 1990s, technologicallyenhanced fieldwork, exploiting the development of GIS, GPS, Google Earth, Geotagging and the potential of pod/vodcasts and Social Networking site has become a major aspect of the fieldwork literature (Warburton \& Higgitt, 1997; Kemp et al., 2012). While much of this literature remains expository and there is a breathless enthusiasm to much, it doubtless heralds a new era of technologically blended fieldwork and perhaps new fieldwork paradigms (Brown, 1999; France and Wakefield, 2011; Fuller \& France, 2015; Jarvis \& Dickie, 2010; Nellis, 1994; McMorrow, 2005; Welsh et al., 2012; Welsh et al, 2013). Of course, the fieldwork role of 'ground-truthing' harks back to some of the UK's earliest thoughts on the purpose of fieldwork. Wooldridge \& East (1951, p. 148) “..the essential nature of training in Geographical fieldwork ... is the comparison of the ground with the map...". However, it has added new dimensions to data collection and interactivity between fieldwork observation and published wisdom undreamt of in earlier decades.

\section{Mode 6: Research Apprenticeship ('Do as I do and learn how I do it')}

"Discovery research dominates in geography departments in universities" and many students wish to be more involved (Healey, 2005, p. 189). However, for many years teaching and research were seen as incompatible, the concept of undergraduate research was anathema, and 
the involvement of undergraduates in professional research activities was a cause for raised eyebrows. In the last decade, with the rise of notions such as Citizen Science and the blurring of boundaries between teaching and research, there has been a steady growth in the integration of staff and undergraduate research. Certainly, undergraduate engagement in research promises a deeper, hands-on experience of the processes of knowledge creation. Similarly, fieldwork, especially in Physical Geography has long been seen as a vehicle for embedding research-based learning throughout the curriculum (Fuller et al., 2014, 2010; Tinsley, 1996). Even so, student engagement in research does not necessarily lead to better learning and it can lead to exploitation; there is an "essential need for linking critical thinking with the doing" so that the approach does not merely result in copycat and 'mini-me' (Healey, 2005, p. 195). Ultimately, the litmus test for successfully engaging students in research may well be the degree to which they are involved as co-learners with the research professionals (Heron et al., 2006). Another test is the degree to which the students are able to become autonomous researchers in their own right, even to publishing their own results (Walkington, 2012; Walkington et al., 2011), a move reminiscent of earlier work to have them create their own learning materials (Higgitt, D., 1996).

\section{Mode 7: Reflective International Fieldwork ('Experience and wonder')}

Much fieldwork writing discusses the significance of immersive experience on learning. However, "it is perhaps time to see fieldwork less as a recording science and more as a performing art" Cosgrove \& Daniels (1989, p.171), introduced the idea of fieldwork as spectacle, with the learners as players in a kind of theatre, sometimes in post-colonial or other roles with important political or ethical positionalities (Abbott, 2006; Sultana, 2007; Patel, 2015). The deep Eurocentric roots of Cosgrove \& Daniels (1989) contrast sharply with the multicultural ambitions of Haigh et al (1995)'s 'Landscape Assay' exercise, which anticipates Twenty-first Century thinking about 'Internationalisation', and cultural pluralism.

Back in 1978, Wright (1978, p.115) noted: "our mental maps of field study areas stop at the end of Europe; beyond that 'geographical expeditions' take over. The rest of the world is fair game for research, but beyond the boundary of ordinary field study." Times change. Today many Departments construct fieldtrips in far flung locations, sometimes because they are field research areas, sometimes because they are powerful marketing and recruitment tools, and just sometimes because of the opportunities they allow for intercultural internationalisation of the curriculum as well as development-related studies. Some of these new studies display not only the sensitivities towards fieldwork's social messages and participatory ethics that have developed since the circum-Millennial affective turn in Geography (when Geographers 
rediscovered the role of emotions, morality and ethics), but also a deeper grasp of pedagogic theory. This is highlighted by the $J G H E$ 's recent symposium on International Geographical Fieldwork (Glass 2015a). Notable contributions include, Mullens \& Cuper (2015), who use Bloom's domains in curriculum design, Glass (2015b) who explores learner reflections on long haul fieldwork using Kemble's 'Taxonomy of Reflexive Practice', Lemmon (2015, p.549), who considers the problems that result because learners tend to "interact with those who are culturally akin to themselves than those who are not" and McMorran (2015), who worries about the tone of field study visits, comparing pan-glossian 'fan-pilgrimage' with 'Dark Tourism' that focuses on negatives. Among the positives of this new approach is an empathic concern for the subjects of the fieldwork, a move away from conceiving the field as simply an object for study, and deeper concern for the emotional effectiveness of the programme.

\section{Discussion}

The Journal of Geography in Higher Education's most cited paper is a fieldwork literature review (Kent et al., 1997). This suggests that the three most significant developments in fieldwork pedagogy in the 1980s and 1990s were: the integration of skills with fieldwork teaching, the growth of class sizes and parallel expansion of ability ranges, and finally the continuing squeeze on financial resources, themes that are still pertinent today. Kent et al. (1997) note that students prefer active to passive learning and conclude by urging more studentcentred field-learning and the need for more autonomy in fieldwork learning, as well as noting the value of using field training as preparation for independent research. However, our review of the pages of the JGHE suggests at least seven modes in the development of fieldwork (Figure 2). These are arrayed as a kind of historical, perhaps evolutionary, sequence but most remain current in geography fieldwork practice. The sequence runs from teaching-oriented through learning-oriented to study subject area focussed and the issues of dealing with the 'Other' (Monk, 2000). It also charts the JGHE's gradual shift away from its original, almost exclusively UK-focus fieldwork toward something rather more international and inclusive.

Previously, Martin Higgitt's exploration of fieldwork pedagogy, introduced ideas of experiential learning, (Higgitt, M., 1996; Healey \& Jenkins, 2000), deep versus surface learning (Marton \& Saljo, 1976; Boyle et al., 2007), and the importance learners place on assessment, along with their associated coping strategies, which can impact negatively on fieldwork. His wishes for future development, most of which are now realised, emphasised a shift to autonomous rather than prescriptive learning, better integration of fieldwork within the 
curriculum, especially more time spent in preparation and follow-through activities, and more imaginative approaches to assessment. Hovorka \& Wolf (2009) update this by exploring the pedagogic development of fieldwork as active learning in a constructivist frame - fieldwork concerns learning by doing. Constructivism arises from the notion that a learner best understands something they have constructed for themselves. Hence, its key pedagogy is to construct learning invitations that persuade the learner to undertake that process of construction and so integrate classroom understanding with real-world problem solving (Fuller, 2006; Haigh, 2011; Pawson et al., 2006). Unusually, the case study by Hovorka \& Wolf (2009) was a 'classroom based' field-course on 'Gender and Environment' at the University of Guelph, whose success is compared with that of a conventional foreign field course experience in its ability to develop key skills in observation and analysis and personal development through deep encounters with the challenges of the field environment.

Today, Martin Higgitt's proposal for more autonomous learning in Geography fieldwork has grown into a full fledged movement that promotes undergraduate research in many formats (Walkington et al., 2011) The undergraduate dissertation, which is taken as a mark of Honours in many undergraduate programmes programmes in the UK, North America, Republic of Ireland, Hong Kong, Malta, etc. is, typically, the major independent research project undertaken by an undergraduate Geographer in these systems. However, this subject received little attention in the journal until relatively recent times, despite the dissertation being called "the pinnacle of studies for an undergraduate programme" (Harrison \& Whalley, 2008, p.401). Gatrell (1991) opens the discussion in the JGHE and his paper's antecedents go back no further than 1983. In some programmes, the Masters paper in taught Masters courses, or the ubiquitous independent paper that completes the coursework for so many HEI courses, serve similar functions but receive even less attention.

Problem-based learning (along with Inquiry-Based learning) have been key to the convergence of teaching and research in fieldwork, with undergraduates taking ever more self-directed roles (Walkington et al., 2011). The formal concept of Problem Based Learning (PBL), by definition - an active-learning strategy that fosters deep learning, was introduced by John Bradbeer (1996), who argued that it was a way of producing critically self-aware, self-directed practitioners. Later, Pawson et al (2006) agreed that it affected learner confidence positively and its student-focus encouraged deeper understanding. Problems include lack of prior experience on the part of many learners, the messiness that results from the creation of project 
teams from inexperienced team-workers, the commitment of staff time, learner insecurity caused by the contradictions of real-world field situations, the real danger of project failure, and deep concerns among instructors about the volume of knowledge gained. Some of these might be offset by good preparation and scenario design, and by making sure that the learners are capable of solving the problem set, have sufficient time to prepare and, if team based, for the group to gel, and include an authentic assessment mechanism that mirrors the PBL process and includes self-assessment by the learners (Spronken-Smith \& Kingham, 2009).

Team management, especially crisis management, in the field remains a neglected aspect of both the research and advisory literature (Maskall \& Stokes, 2008). Until recently, it was assumed that every Geographer with a Ph.D. was equipped to undertake first rate classroom teaching. The idea that those new to teaching in Geography Higher Education would benefit from some teacher training is a product of recent decades and still far from universally accepted. Similarly, the idea that those who lead fieldwork might benefit from additional specialist field trip leadership training has not yet gained much traction, at least outside environments where there are major health and safety risks (Thomas and Munge, 2015). However, such training could also be embedded in the fieldwork curriculum, so enhancing its contribution to the development of leadership graduate attributes; Thomas and Munge (2015) describe a peer-learning fieldwork leadership case study from La Trobe University. Behaviour management issues, often hinted at in institutional policy documents (e.g. Yale College. 2018), may be another area where staff training could be increased. While such issues may be similar in kind to those experienced in classroom settings, teacher-learner contact tends to be much more intensive in field trip situations and assistance much further away (Kuhlenschmidt \& Layne, 1999). To date, few papers deal with problem solving in fieldwork management or what to do when things go wrong (Fuller et al., 2003; Bixler et al., 1994). In the same vein, more research may be needed on the inclusivity aspects of fieldwork, especially to explore differences in experience related to gender, race, culture, sexuality and physical and perceptual abilities (Maguire, 1998; Hall et al., 2002). Reflective field diaries may provide a useful way of accessing such information (Dummer et al. 2008).

The question remains - how much fieldwork and what kind of fieldwork activities are optimal for a Geography curriculum. Fieldwork is a very limited resource in most Geography programmes. However, there is evidence that the more fieldwork learners undertake, the more they appreciate its benefits (Anđelković et al., 2018). Fieldwork is said to connect learners 
with the complexity of real-world situations while simultaneously making them amenable to comprehension (Fuller, 2006). However, exposing Geography learners to occasional, infrequent, fieldwork experiences may have important side-effects; one such is that learners may prove unable to grasp the transience of the conditions in their field setting. If the sun is shining during their field visit, in their imagination, at a very deep level, it is always shining; if a riverbed is dry, it is always dry (Haigh, 2010). Solutions might include ensuring that fieldwork is a more regular part of the curriculum or focussing on particular field locations repeatedly. However, the more cost-effective and easily achieved option might be to supplement the field experience with web-based resources showing, perhaps, historical images of the same location (e.g. Sidaway, 2002), thereby exploiting the fact that most students are already adept 'mobile learners' and skilled in the use of portable technologies such as smart phones and i-Pads (Whalley et al., 2018). It is true that, currently, field course leaders are more positive about the capacity of using such devices in group work than many learners and there remains the problem of inequality between those who have the latest devices and those who do not (Welsh et al., 2018). Looking forward, in the future, it is certain that fieldwork will be increasingly connected through the use of mobile devices. Information will be recorded, accessed and evaluated with greater immediacy in the field. The greater use of blended learning has implications for both the design and execution of field instruction and field project work (France et al., 2016; Fuller \& France, 2014). Mobile technologies offer opportunities to develop new fieldwork pedagogies that will render many past fieldwork strategies obsolete. They facilitate the creation of more personal learning environments and networks; they also enable mapping, data access, recording, storage and sharing, and connect the fieldworker with the media, satellite maps, and all the data of the internet on site (France et al., 2013; 2015). There is much yet to be done to explore the potential applications of these new and evolving capabilities in the reshaping of fieldwork curricula.

New technologies, however, may not solve the problem of the affective detachment of fieldwork learners from the realities that they study, especially in applied and social scientific fieldwork. A good fieldwork experience develops deeper understandings of the places visited than that achievable by even the most enlightened forms of tourism because of its active engagement and deeper connection with the area studied. This is more easily achieved when there is direct engagement with local people, which is why, although the logistics may be challenging, programmes involving reciprocal field trips between universities, where students work together in both host and learner roles in both sending and receiving locations, would be 
an excellent development. One of two models already exist, such as the transcultural reciprocal tandem research summer schools run jointly by the anthropology departments of Gadjah Mada University, Yogyakarta, and the Albert-Ludwigs Universität, Freiburg (Keller, 2011) and another for social workers that links Sapir College, Israel, with the University of Nagpur, India (Nuttman-Schwartz \& Ranz, 2014). However, neither is without its challenges. Preparing geographers for the world of work is an aspect of many curricula. There is scope for greater integration of field-trips with both service learning in the community and engagement with geography practitioners in both the public and private sectors (e.g. Haigh, 2017; Mak et al., 2017). There is already a growing investment in research training for undergraduate geographers, where fieldwork plays a key role (Cheong and Willis, 2015; Walkington et al. 2011).

\section{Conclusion}

Fieldwork is a signature pedagogy of Geography. It is the place where geographers learn to connect classroom theory with the real world, where they learn to practice their geo-capabilities and key geographical skills as well as enhance their general graduate capabilities, such as problem solving, critical thinking, team-working and emotional intelligence. Fieldwork also provides spaces where the range of Geographical skills can be integrated, where our discipline's enormous scope can be brought into play to solve complex problems, across subdisciplinary and specialist boundaries, by treating the landscape as a dynamic whole. Fieldwork is where Geographers learn to 'do' and 'from doing' Geography. Its special attributes include providing experiential, sometimes transformative, learning through immersion of the learner in the field experience. In forty years, the Journal of Geography in Higher Education has helped Geography Fieldwork to move from the margins of the curriculum to, its current place, embedded at its heart. The increase in the frequency of field related publications (Figure 1) in $J G H E$ illustrates the growing interest in reporting and researching diverse pedagogic approaches to fieldwork learning. This has helped Geography Fieldwork transform from a passive 'look see' for individual learners to active and increasingly autonomous learning involving student teamwork, moving away from consumption of received wisdom to the production of new understanding through research and problem solving (Figure 2). It has helped Geography Fieldwork sites transform from being mere objects to be observed, or laboratories for the testing of skills, to living, inhabited, places with real needs, real problems and sensitivities that demand ethical respect. Finally, the Journal of Geography in Higher Education has helped Geography Fieldwork connect with technology, with the networked 
future, and with ubiquitous problems, like sustainability, cross-cultural communication, and environmental change, and find a new mission in solving the problems of the future world.

\section{Acknowledgements}

Thanks to Emma Nadan for her time and assistance with the construction of the Figures in this manuscript. Thanks also to those anonymous reviewers tasked with reviewing this manuscript.

\section{References:}

Abbott, D. (2006). Disrupting the 'whiteness' of fieldwork in geography. Singapore Journal of Tropical Geography, 27(3), 326-341. DOI: 10.1111/j.1467-9493.2006.00265.x

Anđelković, S., Dedjanski, V. \& Pejic, B. (2018) Pedagogical benefits of fieldwork of the students at the Faculty of Geography in the light of the Bologna Process. Journal of Geography in Higher Education, 42(1), 110-125, DOI: 10.1080/03098265.2017.1379058

Bixler, R. D., Carlisle, C. L., Hammltt, W. E., \& Floyd, M. F. (1994). Observed fears and discomforts among urban students on field trips to wildland areas. The Journal of Environmental Education, 26(1), 24-33. DOI: 10.1080/00958964.1994.9941430.

Board, C. (1965). Fieldwork in Geography, with particular reference on the role of Land-Use Survey, Chapter 10. In R.J. Chorley, \& P. Haggett (Eds), Frontiers in Geographical Teaching (pp. 186-214). London: Methuen. ISBN-10: 041616840X; ISBN-13: 978 0416168402.

Boyle, A., Maguire, S., Martin, A., Milsom, C., Nash, R., Rawlinson, S., Turner, A., Wurthmann, S. \& Conchie, S. (2007). Fieldwork is good: The student perception and the affective domain. Journal of Geography in Higher Education, 31(2), 299-317. DOI: 10.1080/03098260601063628.

Bradbeer, J. (1996). Problem-based learning and fieldwork: a better method of preparation? Journal of Geography in Higher Education, 20(1), 11-18. DOI: $10.1080 / 03098269608709340$

Brown, G. H. (1999). A group-learning approach to academic and transferable skills through an exercise in the global positioning system. Journal of Geography in Higher Education, 23(3), 291-301. DOI: 10.1080/03098269985254.

Cheong, S. M., \& Willis, S. (2015). Integrating research and education: Undergraduate fieldwork in geography. Council on Undergraduate Research, Quarterly, 36(1), 40 -45.

Clark, G. (1997). The educational value of the rural trail: a short walk in the Lancashire countryside. Journal of Geography in Higher Education, 21(3), 349-362. DOI: $10.1080 / 03098269708725441$.

Cosgrove, D., \& Daniels, S. (1989). Fieldwork as theatre: a week's performance in Venice and its region. Journal of Geography in Higher Education, 13(2), 169-182. DOI: 10.1080/03098268908709082.

Couper, P., \& Porter, S. (2016). "Environmental awareness" and rock climbing: changing pedagogies to enhance pro-environmental graduate attributes, Journal of Geography in Higher Education, 40:2, 207-221. DOI: 10.1080/03098265.2016.1141187. 
Drengson, A., \& Inoue, Y. (1995). Introduction, pp xvii - xxviii, in Drengson, A., \& Inoue, Y. (eds) (1995). The Deep Ecology Movement: An Introductory Anthology. Berkeley, CA: North Atlantic Books. (Io Series 50). ISBN-10: 1556431988; ISBN-13: 978-1556431982.

Dummer, T. J., Cook, I. G., Parker, S. L., Barrett, G. A., \& Hull, A. P. (2008). Promoting and assessing 'deep learning'in geography fieldwork: An evaluation of reflective field diaries. Journal of Geography in Higher Education, 32(3), 459-479. DOI: $10.1080 / 03098260701728484$

Dunphy, A., \& Spellman, G. (2009). Geography fieldwork, fieldwork value and learning styles. International Research in Geographical and Environmental Education, 18(1), 19-28. DOI: $10.1080 / 10382040802591522$

Ellis, B. (1993). Introducing humanistic geography through fieldwork. Journal of Geography in Higher Education, 17(2), 131-139. DOI: 10.1080/03098269308709215.

Finlayson (1981) The analysis of stream suspended loads as a geomorphological teaching exercise, Journal of Geography in Higher Education, 5(1), 23-35. DOI: 10.1080/03098268108708787.

France, D., Powell, V., Mauchline, A., L., Welsh, K., Park, J., Whalley, W. B., \& Rewhorn, S. (2016). Ability of students to recognize the relationship between using mobile apps for learning during fieldwork and the development of graduate attributes, Journal of Geography in Higher Education, 40:2, 182-192. DOI: 10.1080/03098265.2016.1154931.

France, D., \& Wakefield, K. (2011). How to produce a digital story. Journal of Geography in Higher Education, 35(4), 617-623. DOI: 10.1080/03098265.2011.560658.

France, D., Whalley, B., \& Mauchline, A. (2013). Using mobile devices to enhance undergraduate field research. CUR Quarterly, 34(2), 38-42.

France, D., Whalley, W.B., Mauchline, A., Powell, V., Welsh, K., Lerczak, A., Park, J. \& Bednarz, R.S., (2015). Enhancing fieldwork learning using mobile technologies. Cham, Switzerland, Springer Ecology Briefs. DOI: 10.1007/978-3-319-20967-8.

Fuller, I. C. (2006). What is the value of fieldwork? Answers from New Zealand using two contrasting undergraduate physical geography field trips. New Zealand Geographer, 62(3), 215-220. DOI: $10.1111 / \mathrm{j} .1745-7939.2006 .00072 . x$

Fuller, I., Brook, M., \& Holt, K. (2010). Linking teaching and research in undergraduate physical geography papers: The role of fieldwork. New Zealand Geographer, 66(3), pp 196202. DOI10.1111/j.1745-7939.2010.01187.x.

Fuller, I., Edmondson, S., France, D., Higgitt, D., \& Ratinen, I. (2006). International perspectives on the effectiveness of geography fieldwork for learning. Journal of Geography in Higher Education, 30(1), 89-101. DOI: 10.1080/03098260500499667.

Fuller, I. C, \& France, D. (2014). Fieldwork going digital. In M.J. Thornbush, C.D. Allen \& F.A. Fitzpatrick (Eds), Developments in Earth Surface Processes (Vol. 18, pp. 117-130). Oxford: Elsevier. ISBN-10: 9780444634184; ISBN-13: 0444634185.

Fuller, I. C., \& France, D. (2015). Securing field learning using a twenty- first century Cook's Tour, Journal of Geography in Higher Education, 39(1), 158-172. DOI: 10.1080/03098265.2014.1003801.

Fuller, I. C., \& France, D. (2016). Does digital video enhance student learning in field-based experiments and develop graduate attributes beyond the classroom?, Journal of Geography in Higher Education, 40 (2), 193-206. DOI: 10.1080/03098265.2016.1141186. 
Fuller, I., Gaskin, S., \& Scott, I. (2003). Student perceptions of geography and environmental science fieldwork in the light of restricted access to the field, caused by foot and mouth disease in the UK in 2001. Journal of Geography in Higher Education, 27(1), 79-102. DOI: $10.1080 / 0309826032000062487$.

Fuller, I. C., Mellor, A., \& Entwistle, J. A. (2014). Combining research-based student fieldwork with staff research to reinforce teaching and learning. Journal of Geography in Higher Education, 38(3), 383-400. DOI: 10.1080/03098265.2014.933403.

Gallego Nava, R. (2001). Holistic education: Pedagogy of Universal Love. Brandon VT: Foundation for Educational Renewal. ISBN-13: 978-1885580108; ISBN-10: 188558010X.

Gatrell, A.C. (1991) Teaching students to select topics for undergraduate dissertations in geography, Journal of Geography in Higher Education, 15(1), 15-23. DOI: 10.1080/03098269108709125.

Glass, M.R. (Ed) (2015a). Special issue: JGHE symposium: Practices and challenges of international geography field courses. Journal of Geography in Higher Education 39(4), 485-629. DOI: 10.1080/03098265.2015.1108044.

Glass, M. R. (2015b). Teaching critical reflexivity in short-term international field courses: practices and problems. Journal of Geography in Higher Education, 39(4), 554-567. DOI: 10.1080/03098265.2015.1084610.

Gold, J.R., Jenkins, A., Lee, R., Monk, J., Riley, J., Shepherd, I.D.H. \& Unwin, D.J. (1991). Teaching Geography in Higher Education. Oxford: Blackwell. ISBN 0-631-15726-3.

Graves, N. (1978) Aims and objectives in degree curriculum design. Journal of Geography in Higher Education, 2(2), 64-73. DOI: 10.1080/03098267808708674.

Gray (1981) Large-scale geomorphological field mapping: teaching the first stage, Journal of Geography in Higher Education, 5(1), 37-44. DOI: 10.1080/03098268108708788

Haigh, M. (2008). Coloring in the emotional language of place. Journal of Invitational Theory and Practice 14, 25-40. Retrieved from http://eric.ed.gov/?q=Coloring+in\&id=EJ83952.

Haigh, M. (2010). Exploring sustainability in the context of Land Reclamation: an exercise for Environmental Management trainees. International Journal of Environment and Sustainable Development 9, 255-268. DOI: 10.1504/IJESD.2010.029975.

Haigh, M. (2011). Invitational education: Theory, research and practice. Journal of Geography in Higher Education, 35(2), 299-309. DOI: 10.1080/03098265.2011.554115.

Haigh, M. (2013). Toward the Intercultural Self: Exploring the Effects of Mahatma Gandhi's International Education in London. Cross Cultural Teaching and Learning for Home and International Students. London: Routledge, pp. 196-210. ISBN: 978-0-415-63012-2

Haigh, M. (2016). Fostering deeper critical inquiry with causal layered analysis, Journal of Geography in Higher Education, 40(2), 164-181. DOI: 10.1080/03098265.2016.1141185.

Haigh, M. J. (2017). Connective practices in sustainability education. Journal of Applied Technical and Educational Sciences, 7(4), 6-30.

Haigh, M., \& Gold, J. R. (1993). The problems with fieldwork: a group-based approach towards integrating fieldwork into the undergraduate geography curriculum. Journal of Geography in Higher Education, 17(1), 21-32. DOI: 10.1080/03098269308709203. 
Haigh, M. J., Revill, G., \& Gold, J. R. (1995). The landscape assay: exploring pluralism in environmental interpretation. Journal of Geography in Higher Education, 19(1), 41-55. DOI: $10.1080 / 03098269508709287$.

Hall, T., Healey, M., \& Harrison, M. (2002). Fieldwork and disabled students: discourses of exclusion and inclusion. Transactions of the Institute of British Geographers, 27(2), 213231. DOI: $10.1111 / 1475-5661.00050$.

Harrison, M.E. \& Whalley, W.B. (2008) Undertaking a dissertation from start to finish: the process and product, Journal of Geography in Higher Education, 32(3),401-418. DOI: 10.1080/03098260701731173.

Healey, M. (2005). Linking research and teaching to benefit student learning. Journal of Geography in Higher Education, 29(2), 183-201. DOI: 10.1080/03098260500130387.

Healey, M., \& Jenkins, A. (2000). Kolb's experiential learning theory and its application in geography in higher education. Journal of Geography, 99(5), 185-195. DOI: 10.1080/00221340008978967.

Heron, R. L., Baker, R., \& McEwen, L. (2006). Co-learning: Re-linking research and teaching in geography. Journal of Geography in Higher Education, 30(1), 77-87. DOI: 10.1080/03098260500499659.

Higgitt, D. L. (1996). The effectiveness of student-authored field trails as a means of enhancing geomorphological interpretation. Journal of Geography in Higher Education, 20(1), 35-44. DOI: $10.1080 / 03098269608709343$.

Higgitt, M. (1996). Addressing the new agenda for fieldwork in higher education. Journal of Geography in Higher Education, 20(3), 391-398. DOI: 10.1080/03098269608709382.

Hill, J., \& Walkington, H. (2016). Developing graduate attributes through participation in undergraduate research conferences, Journal of Geography in Higher Education, 40(2), 222-237. DOI: 10.1080/03098265.2016.1140128.

Hill, J., Walkington, H., \& France, D. (2016). Graduate attributes: implications for higher education practice and policy, Journal of Geography in Higher Education, 40(2), 155-163. DOI: $10.1080 / 03098265.2016 .1154932$.

Houser, C., Brannstrom, C., Quiring, S. M., \& Lemmons, K. K. (2011). Study abroad field trip improves test performance through engagement and new social networks. Journal of Geography in Higher Education, 35(4), 513-528. DOI: 10.1080/03098265.2010.551655.

Hovorka, A. J., \& Wolf, P. A. (2009). Activating the classroom: Geographical fieldwork as pedagogical practice. Journal of Geography in Higher Education, 33(1), 89-102. DOI: 10.1080/03098260802276383.

Jenkins, A. (1994). Thirteen ways of doing fieldwork with large classes/more students. Journal of Geography in Higher Education, 18(2), 143-154. DOI: 10.1080/03098269408709250.

Jenkins, T. (1994). Fieldwork and the perception of everyday life. Man, 29, 433-455. DOI: $10.2307 / 2804481$.

Jarvis, C., \& Dickie, J. (2010). Podcasts in support of experiential field learning. Journal of Geography in Higher Education, 34(2), 173-186. DOI: 10.1080/03098260903093653

Kasimov, N. S., Chalov, S. R., \& Panin, A. V. (2013). Multidisciplinary field training in undergraduate Physical Geography: Russian experience. Journal of Geography in Higher Education, 37(3), 416-431. DOI: 10.1080/03098265.2013.794331 
Keene, P. (1982). The examination of exposures of pleistocene sediments in the field: a selfpaced exercise. Journal of Geography in Higher Education, 6(2), 109-121. DOI: $10.1080 / 03098268208708848$.

Keene, P. (1989) Trails on trial, Environmental Interpretation, 44(1), 15-16.

Keller, A. (2011) Indonesier erforschen Deutsche: Zu Besuch bei strenggläubigen Veganern. Speigel online. Retrieved from: http://www.spiegel.de/unispiegel/studium/0,1518,797858,00.htm.

Kemp, J., Mellor, A., Kotter, R., \& Oosthoek, J. W. (2012). Student-produced podcasts as an assessment tool: An example from geomorphology. Journal of Geography in Higher Education, 36(1), 117-130.

Kent, M., Gilbertson, D. D., \& Hunt, C. O. (1997). Fieldwork in geography teaching: A critical review of the literature and approaches. Journal of Geography in Higher Education, 21(3), 313-332. DOI: 10.1080/03098269708725439.

Kern, E. L., \& Carpenter, J. R. (1984). Science through a field-oriented approach. Journal of Geological Education, 32(5), 299-305. DOI: 10.5408/0022-1368-32.5.299.

Kern, E. L., \& Carpenter, J. R. (1986). Effect of field activities on student learning. Journal of Geological Education, 34(3), 180-183. DOI: 10.5408/0022-1368-34.3.180

Kuhlenschmidt, S. L., \& Layne, L. E. (1999). Strategies for dealing with difficult behavior. New directions for teaching and learning, 77, 45-57. DOI: 10.1002/t1.7705.

Lemmons, K. (2015). Short-term study abroad: culture and the path of least resistance. Journal of Geography in Higher Education, 39(4), 543-553

Leydon, J., \& Turner, S. (2013). The challenges and rewards of introducing field trips into a large introductory Geography class. Journal of Geography, 112(6), 248-261. DOI: $10.1080 / 00221341.2013 .833279$.

Lloyd, K., Howitt, R., Bilous, R., Clark, L., Dowling, R., Fagan, R., Fuller, S., Hammersley, L, Houston, D., McGregor, A., McLean, J., Miller, F., Ruming, K., Semple A-L., \& SuchetPearson, S. (2015). Geographic contributions to institutional curriculum reform in Australia: the challenge of embedding field-based learning. Journal of Geography in Higher Education, 39(4), 491-503. DOI: 10.1080/03098265.2015.1103710.

Maguire, S. (1998). Gender differences in attitudes to undergraduate fieldwork. Area, 30(3), 207-214. DOI:10.1111/j.1475-4762.1998.tb00065.x

Mak, B., Lau, C. \& Wong, A. (2017) Effects of experiential learning on students: an ecotourism service-learning course. Journal of Teaching in Travel \& Tourism, 17(2), 85-100, DOI: $10.1080 / 15313220.2017 .1285265$

Maskall, J., \& Stokes, A. (2008). Designing effective fieldwork for the environmental and natural sciences. GEES Teaching and Learning guide. Plymouth, HE Academy Subject Centre for Geography, Earth and Environmental Sciences. ISBN: 978-1-84102-201-7. Retrieved from: https://www.heacademy.ac.uk/knowledge-hub/designing-effectivefieldwork-environmental-and-natural-sciences.

Marton, F. \& Saljo, R. (1976). On qualitative differences in learning, I: Outcome and process, British Journal of Educational Psychology, 46, 4-11. DOI: 10.1111/j.20448279.1976.tb02980.x. 
Marvell, A., Simm, D., Schaaf, R., \& Harper, R. (2013). Students as scholars: evaluating student-led learning and teaching during fieldwork. Journal of Geography in Higher Education, 37(4), 547-566. DOI: 0.1080/03098265.2013.811638.

McEwen, L. (1996). Fieldwork in the undergraduate geography programme: challenges and changes. Journal of Geography in Higher Education, 20(3), 379-384. DOI: 10.1080/03098269608709380.

McMorran, C. (2015). Between fan pilgrimage and dark tourism: competing agendas in overseas field learning. Journal of Geography in Higher Education, 39(4), 568-583. DOI: 10.1080/03098265.2015.1084495

McMorrow, J. (2005). Using a Web-based resource to prepare students for fieldwork: Evaluating the Dark Peak virtual tour. Journal of Geography in Higher Education, 29(2), 223-240. DOI: 10.1080/03098260500130445.

Moles, R. (1977) Biogeographical field study of farmland, Journal of Geography in Higher Education, 1(2), 20-26. DOI: 10.1080/03098267708708623.

Monk, J. (2000). Looking out, looking in: The 'other' in the journal of geography in higher education. Journal of Geography in Higher Education, 24(2), 163-177. DOI: $10.1080 / 03098260050077463$

Mullens, J. B., \& Cuper, P. (2015). A curriculum framework for faculty-led international programs in geography. Journal of Geography in Higher Education, 39(4), 504-512. DOI: 10.1080/03098265.2015.1084498.

Mullens, J. B., Bristow, R. S., \& Cuper, P. (2012). Examining trends in international study: A survey of faculty-led field courses within American departments of geography. Journal of Geography in Higher Education, 36(2), 223-237. DOI: 10.1080/03098265.2011.619521.

Nellis, M. D. (1994). Technology in geographic education: Reflections and future directions. Journal of Geography, 93(1), 36-39. DOI: 10.1080/00221349408979683.

Nuttman-Shwartz, O. \& Ranz, R. (2014). A Reciprocal Working Model for Fieldwork with International Social Work Students, The British Journal of Social Work, 44(8), 2411-2425. DOI: $10.1093 / \mathrm{bjsw} / \mathrm{bct} 080$.

O'Riordan, T. (1978) An example of environmental education, Journal of Geography in Higher Education, 2(2), 3-16. DOI: 10.1080/03098267808708665.

Patel, K. (2015). Teaching and learning in the tropics: an epistemic exploration of "the field" in a development studies field trip. Journal of Geography in Higher Education, 39(4), 584594. DOI: $10.1080 / 03098265.2015 .1084499$.

Pawson, E., Fournier, E., Haigh, M., Muniz, O., Trafford, J., \& Vajoczki, S. (2006). Problembased learning in geography: towards a critical assessment of its purposes, benefits and risks. Journal of Geography in Higher Education, 30(1), 103-116. DOI: 10.1080/03098260500499709.

Pawson, E. \& Teather, E. K. (2002). 'Geographical expeditions': assessing the benefits of a student-driven fieldwork method, Journal of Geography in Higher Education, 26(3), 275289. DOI: $10.1080 / 0309826022000019864$.

Powell, R. C. (2002). The Sirens' voices? Field practices and dialogue in geography. Area, 34(3), 261-272. DOI: 10.1111/1475-4762.00080.

Rose, G. (1993). Feminism \& geography: The limits of geographical knowledge. Cambridge: Polity Press. ISBN-10: 0745611567; ISBN-13: 978-0745611563. 
Scott, I., Fuller, I., \& Gaskin, S. (2006). Life without fieldwork: Some lecturers' perceptions of geography and environmental science fieldwork. Journal of Geography in Higher Education, 30(1), 161-171. DOI: 10.1080/03098260500499832.

Sidaway, J. D. (2002). Photography as geographical fieldwork. Journal of Geography in Higher Education, 26(1), 95-103. DOI: 10.1080/03098260120110395

Silk, J., \& Bowlby, S. (1981). The use of project work in undergraduate geography teaching. Journal of Geography in Higher Education, 5(2), 155-162. DOI: $10.1080 / 03098268108708813$.

Simpson, B. (2006). "You don't do fieldwork, fieldwork does you": between subjectivation and objectivation in anthropological fieldwork, Chapter 8 in: Hobbs, D. \& Wright, R. (eds) The SAGE Handbook of Fieldwork (pp. 125-137) Thousand Oaks, CA, SAGE. DOI: http://dx.doi.org/10.4135/9781848608085.n8.

Spronken-Smith, R. (2013). Toward securing a future for geography graduates. Journal of Geography in Higher Education, 37(3), 315-326. DOI: 10.1080/03098265.2013.794334.

Spronken-Smith, R., \& Kingham, S. (2009). Strengthening teaching and research links: the case of a pollution exposure inquiry project. Journal of Geography in Higher Education, 33(2), 241-253. DOI: 10.1080/03098260802276813

Spronken-Smith, R., Bullard, J. O., Ray, W., Roberts, C., \& Keiffer, A. (2008). Where might sand dunes be on Mars? Engaging students through inquiry-based learning in geography. Journal of Geography in Higher Education, 32(1), 71-86. DOI: 10.1080/03098260701731520.

Spronken-Smith, R., McLean, A., Smith, N., Bond, C., Jenkins, M., Marshall, S., \& Frielick, S. (2016). A toolkit to implement graduate attributes in geography curricula, Journal of Geography in Higher Education, 40:2, 254-266. DOI: 10.1080/03098265.2016.1140129.

Staszak, J. F. (2009). Other/otherness. In Kitchin, R., \& Thrift, N. (eds). International Encyclopedia of Human Geography, 8. Oxford, Elsevier Science, pp 43-47. DOI: 10.1016/B978-008044910-4.00980-9.

Sultana, F. (2007). Reflexivity, positionality and participatory ethics: Negotiating fieldwork dilemmas in international research. ACME: An International E-Journal for Critical Geographies, 6(3), 374-385. Retrieved from: https://www.acmejournal.org/index.php/acme/article/view/786.Tagore, R. (1930). The Religion of Man. Rhinebeck, NY: Monkfish (2004 edition). ISBN-10: 8171676286; ISBN-13: 9788171676286.

Thomas, G., \& Munge, B. (2015). Best practice in outdoor environmental education fieldwork. In: Robertson M., Lawrence R., Heath G. (eds)Experiencing the Outdoors Rotterdam, Sense Publishers, pp. 165-176. DOI: 10.1007/978-94-6209-944-9_14

Tinsley, H. M. (1996). Training undergraduates for self-directed field research projects in physical geography: problems and possible solutions. Journal of Geography in Higher Education, 20(1), 55-64. DOI: 10.1080/03098269608709345.

Tagore, R. (1930). The Religion of Man. Rhinebeck, NY: Monkfish (2004 edition).

Trahar, S. (2011). Developing Cultural Capability in International Higher Education: a narrative inquiry. Abingdon: Routledge. ISBN-10: 041557238X; ISBN-13: 9780415572385. 
Walkington, H. (2012). Developing dialogic learning space: The case of online undergraduate research journals. Journal of Geography in Higher Education, 36(4), 547-562. DOI: 10.1080/03098265.2012.692072.

Walkington, H., Griffin, A. L., Keys-Mathews, L., Metoyer, S. K., Miller, W. E., Baker, R., \& France, D. (2011). Embedding research-based learning early in the undergraduate geography curriculum. Journal of Geography in Higher Education, 35(3), 315-330. Doi: $10.1080 / 03098265.2011 .563377$.

Warburton, J., \& Higgitt, M. (1997). Improving the preparation for fieldwork with 'IT': Two examples from physical geography. Journal of Geography in Higher Education, 21(3), 333 347. DOI: 10.1080/03098269708725440.Welsh, K. E., France, D., Whalley, W. B., \& Park, J. R. (2012). Geotagging photographs in student fieldwork. Journal of Geography in Higher Education, 36(3), 469-480. DOI: 10.1080/03098265.2011.647307.

Welsh, K. E., France, D., Whalley, W. B., \& Park, J. R. (2012). Geotagging photographs in student fieldwork. Journal of Geography in Higher Education, 36(3), 469-480.

Welsh, K. E., Mauchline, A. L., France, D., Powell, V., Whalley, W. B., \& Park, J. (2018). Would Bring Your Own Device (BYOD) be welcomed by undergraduate students to support their learning during fieldwork?. Journal of Geography in Higher Education, 42(3), 356-371, DOI:10.1080/03098265.2018.1437396.

Welsh, K. E., Mauchline, A. L., Park, J. R., Whalley, W. B., \& France, D. (2013). Enhancing fieldwork learning with technology: practitioner's perspectives. Journal of Geography in Higher Education, 37(3), 399-415. DOI: 10.1080/03098265.2013.792042.

Whalley, W. B., Mauchline, A. L., France, D., Park, J., \& Welsh, K. (2018). The iPad six years on: Progress and Problems for Enhancing Mobile Learning with Special Reference to Fieldwork Education. In Crompton, $\mathrm{H}$ \& Traxler, J. (eds) Mobile Learning in Higher Education: Challenges in context. New York, Routledge, pp. 8-18. ISBN: 9781315296722.

Wooldridge, S.W. \& East, W.G. (1951). The Spirit and Purpose of Geography. London, Hutchinson. Retrieved from: https://archive.org/stream/spiritandpurpose $011208 \mathrm{mbp} /$ spiritandpurpose $011208 \mathrm{mbp}$ djvu. txt.

Wright, D. (1978). Field study: Why not the Third World? Journal of Geography in Higher Education, 2(2), 115-117.

Yale College (2018) Academic Field Trip Policies. New Haven, CT, Yale University. Retrieved from: https://yalecollege.yale.edu/deans-office/policies-reports/academic-fieldtrip-policies (2 April, 2018) 
Figure 1. Proportion of articles with 'Field" in the title published in JGHE 1977 - 2016

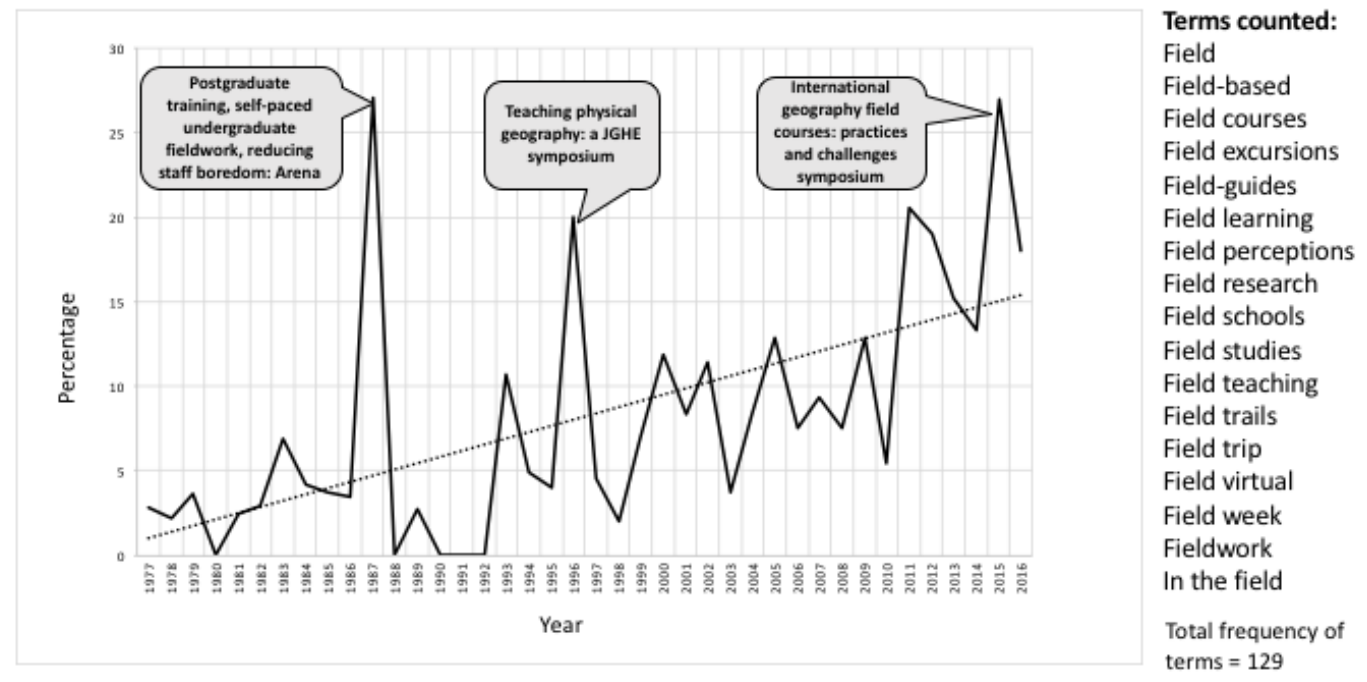

Figure 2. Seven Modes of Fieldwork in Geography Higher Education

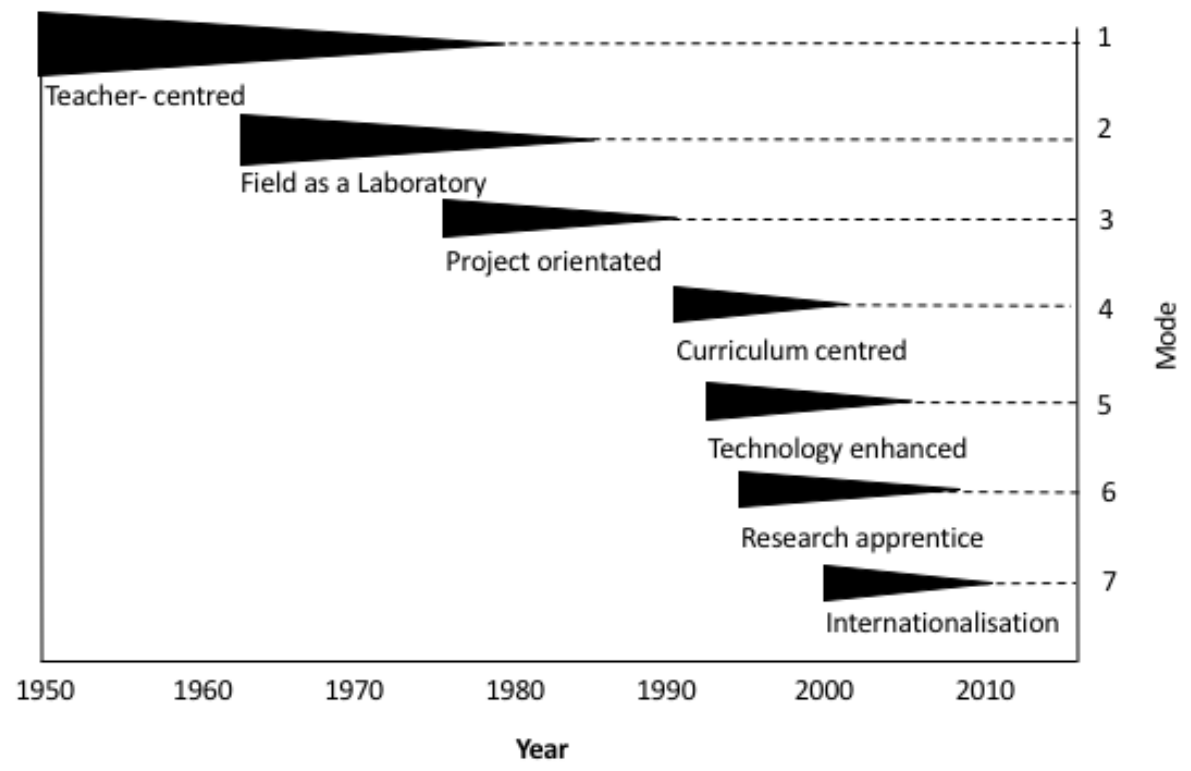

